\title{
Bentuk Keterlibatan Masyarakat dalam Upaya Penghijauan pada Kawasan Hunian Padat di Kelurahan Serengan - Kota Surakarta
}

\author{
Eko Anton Rubiantoro ${ }^{1}$, Ragil Haryanto ${ }^{2}$
}

Diterima : 1 Oktober 2013

Disetujui : 16 Oktober 2013

\begin{abstract}
Greening is an important activities that should be carried out conceptually in dealing the environmental crisis. Serengan Village is one of the kampung which is actively supporting the greening program in Surakarta. Community and relevant stakeholders have committed various greening activities efforts to rescue the environment in Serengan. The purpose of this study is to examine how the forms of community involvement in the greening efforts in high density residential areas in Serengan, Surakarta. This research was conducted using quantitative and qualitative approach with case study research strategy. Based on our research, we have knowed that the society has been involved in the planning, providing, maintening, and supervision of the greening activities. Serengan community assessed that the condition of the green space in the village is very minimal at this time. The greening activities was performed by community in various motives, such as: to increase the ecological value, to improve the aesthetic value, to get the economic benefit, and to support the government programs. The existence of stakeholders consisting of City Government, Local Government, Non-Government Institutions, Private/CSR, and Green Community/Academics have greatly contributed helping the development of greening activities in the study area.
\end{abstract}

Keywords: model of community engagement, greening, high density residential

\begin{abstract}
ABSTRAK
Penghijauan merupakan salah satu kegiatan penting yang harus dilaksanakan secara konseptual dalam menangani krisis lingkungan. Kelurahan Serengan merupakan salah satu kelurahan yang cukup aktif dalam mendukung program penghijauan di Kota Surakarta. Dalam upaya penyelamatan lingkungan, masyarakat bersama stakeholder terkait telah melakukan berbagai kegiatan penghijauan. Penelitian ini bertujuan untuk mengkaji tentang bagaimana bentuk keterlibatan masyarakat dalam upaya penghijauan pada kawasan hunian padat di Kelurahan Serengan - Kota Surakarta. Penelitian ini dilakukan dengan menggunakan metode pendekatan kuantitatif dan kualitatif dengan strategi penelitian studi kasus. Berdasarkan hasil penelitian, diketahui bahwa masyarakat telah terlibat dalam proses perencanaan, penyediaan, pemeliharaan, serta pengawasan kegiatan penghijauan. Masyarakat menilai kondisi ruang hijau di kelurahan saat ini sudah sangat minim. Kegiatan penghijauan dilakukan oleh masyarakat dengan berbagai motif, antara lain : untuk menambah nilai ekologi, manambah nilai estetika, mendapatkan manfaat ekonomi, serta alasan untuk mendukung program pemerintah. Keberadaaan stakeholder yang terdiri dari Pemerintah Kota, Pemerintah Kelurahan, Lembaga Non Pemerintah, Swasta/CSR, dan Komunitas/Akademisi telah berkontribusi besar membantu perkembangan kegiatan penghijauan di wilayah studi.
\end{abstract}

Kata kunci: bentuk keterlibatan masyarakat, penghijauan, kawasan hunian padat

\footnotetext{
${ }^{1}$ Mahasiswa Magister Pembangunan Wilayah dan Kota, Undip, Semarang, Jawa Tengah

${ }^{2}$ Dosen Jurusan Perencanaan Wilayah dan Kota, Undip, Semarang, Jawa Tengah

Kontak Penulis : ruby_ple@yahoo.co.id
} 


\section{PENDAHULUAN}

Penghijauan merupakan salah satu kegiatan penting yang harus dilaksanakan secara konseptual dalam menangani krisis lingkungan. Dalam konteks keruangan, penghijauan sangat dibutuhkan terutama untuk kota-kota yang sedang berkembang dan mengalami alih fungsi ruang untuk kawasan terbangun (Kelvin, 2008). Kota Surakarta merupakan salah satu kota di Indonesia yang gencar melakukan gerakan-gerakan penghijauan. Pertambahan penduduk yang begitu cepat telah mengakibatkan terjadinya densifikasi penduduk dan permukiman yang cepat dan tidak terkendali (Sihono, 2003). Gerakan penghijauan tersebut dilakukan sebagai salah satu upaya penyelamatan lingkungan akibat adanya pertambahan jumlah penduduk yang begitu cepat di kota ini. Kegiatan penghijauan pun dilakukan secara merata sampai dengan tingkat kelurahan (Samsudi, 2010).

Kelurahan Serengan termasuk kelurahan yang cukup aktif dalam mendukung program penghijauan di Kota Surakarta. Alih fungsi lahan yang begitu cepat di kelurahan ini merupakan salah satu faktor yang mendorong masyarakat untuk melakukan penghijauan (Sihono, 2003). Secara spasial kelurahan ini tidak begitu luas, akan tetapi tingkat kepadatan penduduknya sangat tinggi akibat adanya migrasi penduduk dari pusat Kota Surakarta menuju ke kelurahan ini (Setianingrum, 2010). Menurut Tyaswening (2012), kecenderungan migrasi yang terjadi di Kelurahan Serengan, diakibatkan oleh beberapa faktor, antara lain masyarakat lebih memilih tinggal di kelurahan ini karena alasan dekat dengan tempat kerja, harga lahan yang masih murah, serta masyarakat memandang bahwa kelurahan ini masih asri.

Dengan semakin berkembangnya kelurahan ini, berbagai permasalahan pun muncul. Berdasarkan temuan Prasetyo (2013), terdapat berbagai permasalahan lingkungan di Kelurahan Serengan, seperti: hunian yang padat, jalan lingkungan permukiman yang sempit, kepadatan bangunan yang cukup tinggi, dan minimnya ketersediaan hijauan kota akibat besarnya alih fungsi lahan yang terjadi. Masih berdasarkan temuan Prasetyo (2013), alih fungsi lahan di Kelurahan Serengan tergolong tinggi. Kebutuhan akan tempat tinggal menjadi faktor penyebab adanya alih fungsi lahan. Hal ini kemudian berimplikasi pada terjadinya permasalahan utama di Kelurahan Serangan, yaitu semakin berkurangnya ruang untuk penghijauan kota.

Menyikapi keadaan yang begitu krodit, masyarakat Kelurahan Serengan bersama dengan stakeholder terkait di kelurahan ini, telah berhasil mengubah wajah kelurahan yang padat menjadi kawasan hunian yang hijau dan tampak asri. Kenyataan dilapangan yang berupa permukiman padat hunian dengan jalan yang sempit tidak menghalangi masyarakat setempat untuk berinovasi, salah satunya melalui kegiatan penghijauan. Masyarakat di kelurahan ini telah melakukan alternatif peningkatan ruang hijau kota melalui penghijauan atap rumah/bangunan (roof garden), penghijauan pekarangan di halaman rumah, penghijauan melalui media pot, serta berbagai bentuk penghijauan lainnya (Setianingrum, 2010).

Warga Serengan cukup antusias dalam kegiatan penghijauan jauh sebelum program pemerintah masuk. Penghijauan pekarangan biasa dilakukan oleh masyarakat Kelurahan Serengan dengan memanfaatkan sisa-sisa lahan di sekitar pagar rumah penduduk (Arum, 2009). Awal mula dari gagasan ini adalah adanya keprihatinan warga setempat akan keadaan lingkungan hunian mereka yang semakin panas akibat padatnya bangunan. Sehingga pada tahun 2006 warga mulai berinisiatif untuk menanam tanaman hias disela-sela halaman masingmasing. Atas prakarsa salah satu tokoh masyarakat di RW III yaitu Bapak Sri Harjanto, 
masyarakat di RW ini diajak untuk mempelopori program penghijauan di lingkungan mereka (Vidya, 2011).

Dugaan awal dari penelitian ini adalah bahwa masyarakat telah melakukan upaya penghijauan ditengah kawasan hunian padat yang mereka tinggali. Dari dugaan awal ini, lalu pertanyaan penelitian yang muncul adalah: (1) Apa yang melatarbekangi masyarakat di Kelurahan Serengan melakukan penghijauan? Dan apa motif utama masyarakat melakukan penghijauan? (2) Siapa saja yang terlibat dalam upaya penghijauan tersebut? Dan apa peran mereka? (3) Lalu apa bentuk keterlibatan masyarakat dalam kegiatan penghijauan tersebut?

Bersasarkan pertanyaan penelitian, maka penelitian ini bertujuan untuk mengkaji tentang bagaimana bentuk keterlibatan dalam upaya penghijauan pada kawasan hunian padat di Kelurahan Serengan - Kota Surakarta. Adapun sasaran untuk mencapai tujuan dari penelitian tersebut, maka peneliti perlu: 1). Mengkaji tentang persepsi masyarakat terhadap lingkungan huniannya, 2). Mengkaji tentang persepsi masyarakat terhadap kondisi ruang hijau di Kelurahan Serengan, 3). Mengkaji tentang preferensi masyarakat melakukan penghijauan, 4). Mengkaji tentang peran stakeholder dalam upaya-upaya penghijauan, serta 5). Mengkaji tentang bentuk keterlibatan masyarakat dalam upaya penghijauan.

Manfaat yang dapat diambil dari penelitian ini adalah sebagai berikut: 1). Memberikan kontribusi dalam pengembangan teori perencanaan dan pembangunan kota khususnya terkait upaya penghijauan pada kawasan hunian padat. 2). Memberikan gambaran secara nyata bahwa kegiatan penghijauan merupakan tanggung jawab semua pihak, baik itu pemerintah, masyarakat, maupun stakeholder terkait. 3). Dapat digunakan sebagai masukan untuk mengevaluasi kebijakan-kebijakan pembangunan pemerintah kota, khususnya di Kota Surakarta menyangkut upaya penghijauan melalui bentuk kemitraan pemerintah dan swasta (publik-private patnership).

\section{METODE PENELITIAN}

Penelitian ini menggunakan pendekatan kuantitatif dan kualitatif dengan strategi penelitian studi kasus. Teknik pengumpulan data dalam penelitian ini dilakukan melalui dilakukan dua cara, yaitu teknik pengumpulan data primer melalui observasi lapangan dan wawancara, serta teknik pengumpulan sekunder melalui kajian (telaah) dokumen. Partisipan dalam penelitian ini terdiri dari 2 kelompok, yaitu responden yang menjawab kuesioner dan informan untuk wawancara mendalam.

Responden digunakan untuk menilai dan memahami tentang persepsi masyarakat terhadap lingkungan huniannya, persepsi masyarakat terhadap kondisi ruang hijau, serta preferensi masyarakat melakukan penghijauan. Tehnik sampling yang digunakan pada penelitian ini adalah teknik proporsi populasi. Teknik ini menggunakan cara pengambilan sampel secara pilihan acak (Arikunto, 2000). Penentuan populasi yang diambil dalam penelitian ini adalah dengan menggunakan metode sampel acak sederhana (Random Sampling). Jumlah populasi yang digunakan adalah jumlah Kepala Keluarga (KK). Jumlah Kepala Keluarga di Kelurahan Serengan adalah $(\mathrm{N})=2.787 \mathrm{KK}$. Secara umum, jumlah ukuran sampel yang dibutuhkan dapat dihitung dengan menggunakan rumus Pasaribu (1983):

$$
s=\frac{N}{\left(N d^{2}\right)+1} \quad s=\frac{2.787}{\left(2.787(0,1)^{2}\right)+1}=97,95 \quad \approx 100
$$


Dalam penentuan jumlah sampel pada masing-masing RW ditetapkan berdasarkan metoda proporsional (Propotionate). Adapun hasil perhitungannya sebagaimana Tabel 1.

TABEL 1

SAMPEL PER RT DI WILAYAH STUDI

\begin{tabular}{|c|c|c|c|c|}
\hline No. & RW & Populasi & Proporsional $(\mathbf{P}=\mathbf{N} / \mathbf{\Sigma N})$ & Jumlah Sampel $(\mathbf{n}=\mathbf{P} \times \mathbf{1 0 0} \%)$ \\
\hline 1 & RW 1 & 190 & 0,0682 & 7 \\
\hline 2 & RW 2 & 219 & 0,0786 & 8 \\
\hline 3 & RW 3 & 225 & 0,0807 & 8 \\
\hline 4 & RW 4 & 238 & 0,0854 & 8 \\
\hline 5 & RW 5 & 231 & 0,0829 & 5 \\
\hline 6 & RW 6 & 126 & 0,0452 & 5 \\
\hline 7 & RW 7 & 132 & 0,0474 & 5 \\
\hline 8 & RW 8 & 131 & 0,0470 & 5 \\
\hline 9 & RW 9 & 144 & 0,0517 & 4 \\
\hline 10 & RW 10 & 118 & 0,0423 & 8 \\
\hline 11 & RW 11 & 236 & 0,0847 & 9 \\
\hline 12 & RW 12 & 241 & 0,0865 & 8 \\
\hline 13 & RW 13 & 233 & 0,0836 & 7 \\
\hline 14 & RW 14 & 186 & 0,0667 & 5 \\
\hline 15 & RW 15 & 137 & 0,0492 & 100 \\
\hline
\end{tabular}

Sumber: Hasil Analisis, 2013

Informan digunakan untuk mengetahui peran stakeholder dan bentuk keterlibatan masyarakat dalam upaya penghijauan, serta berfungsi sebagai media verifikasi dan pendalaman temuan dari informasi kuesioner. Informan dalam wawancara meliputi : pihak pemerintah setempat, lembaga non pemerintah, ketua RW, serta ketua paguyuban setempat yang dianggap memahami tentang kegiatan penghijauan di Kelurahan Serengan. Proses snowballing dilakukan dalam penelitian ini. Informan yang dimaksud adalah sebagaimana Tabel 2.

TABEL 2

INFORMAN WAWANCARA

\begin{tabular}{|c|c|}
\hline Responden & Alasan \\
\hline $\begin{array}{l}\text { Kepala Kantor Kelurahan ataı } \\
\text { Stafnya ( } 1 \text { responden) }\end{array}$ & $\begin{array}{l}\text { Kepala kantor kelurahan mengetahui secara rinci tentang } \\
\text { bentuk-bentuk penghijauan yang ada diwilayah studi, serta } \\
\text { mengetahui peran stakseholder dan bentuk keterlibatan } \\
\text { masyarakat dalam upaya penghijauan di Kelurahan Serengan. }\end{array}$ \\
\hline Ketua LPMK (1 responden) & $\begin{array}{l}\text { Memiliki informasi kegiatan masyarakat, organisasi- } \\
\text { organisasi kemasyarakatan, dan tingkat partisipasi warga. }\end{array}$ \\
\hline $\begin{array}{l}\text { Ketua RW } \\
\text { Responden) }\end{array}$ & $\begin{array}{l}\text { Memiliki informasi kegiatan masyarakat dan tingkat } \\
\text { partisipasi masyarakat dalam upaya-upaya penghijauan pada } \\
\text { tingkat RW. }\end{array}$ \\
\hline 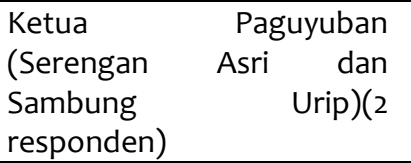 & $\begin{array}{l}\text { Memiliki informasi kegiatan masyarakat, } \\
\text { organisasi kemasyarakatan, dan tingkat } \\
\text { masyarakat dalam upaya-upaya penghijauan }\end{array}$ \\
\hline
\end{tabular}

Sumber: Penyusun, 2013 


\section{GAMBARAN UMUM}

Secara administrasi Kelurahan Serengan memiliki batas sebelah Utara berbatasan dengan Kelurahan Kratonan, sebelah Timur berbatasan dengan Kelurahan Danukusuman, sebelah Selatan berbatasan dengan Kabupaten Sukoharjo, dan sebelah Barat berbatasan dengan Kelurahan Tipes. Kelurahan Serengan merupakan salah satu kelurahan di Kecamatan Serengan yang terletak di sebelah selatan Kota Surakarta. Secara spasial lokasi studi dapat dilihat pada gambar berikut:

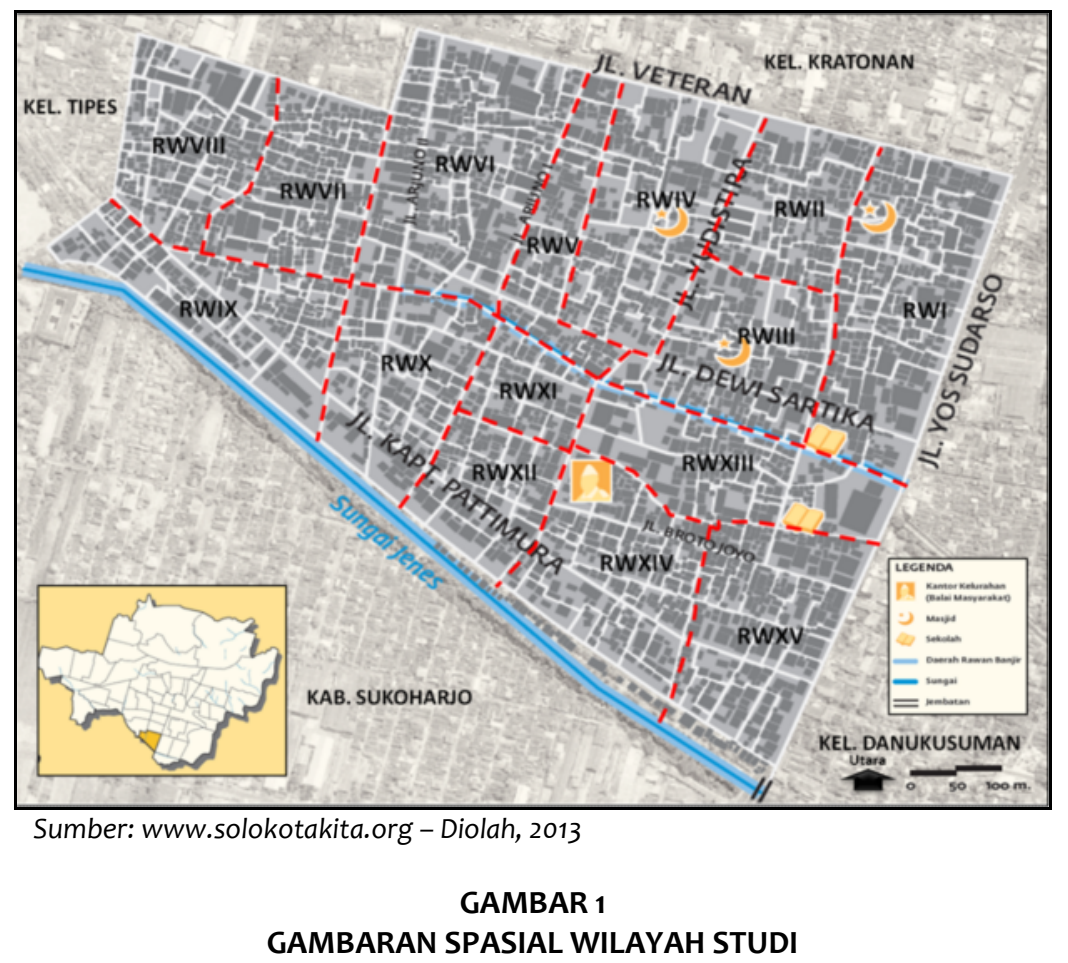

Luas Kelurahan Serengan kurang lebih 64 hektar. Jumlah penduduk Kelurahan Serengan pada Bulan Desember 2012 tercatat sebanyak 11.751 jiwa, sehingga kepadatan penduduk di kelurahan ini adalah 183 jiwa per hektar. Kelurahan Serengan terdiri dari 2.787 Kepala Keluarga (KK) yang tersebar di 15 RW atau 64 RT (Monografi Kelurahan Serengan, 2012).

Adapun bentuk-bentuk penghijauan yang ada di Kelurahan Serengan, dibedakan menjadi penghijauan privat dan penghijauan publik. Untuk bentuk penghijauan privat, contohnya berupa: Penghijauan Pekarangan, Penghijauan atap rumah (roof garden), penghijauan di kawasan komersil, penghijauan di kawasan perkantoran/pendidikan, dan penghijauan privat lainnya. Untuk jenis penghijauan publik, contohnya berupa: penghijauan taman, penghijauan jalur hijau jalan, penghijauan sempadan sungai, dan penghijauan publik lainnya. Adapun contoh bentuk penghijauan yang ada di Kelurahan Serengan dapat di lihat pada gambar berikut: 

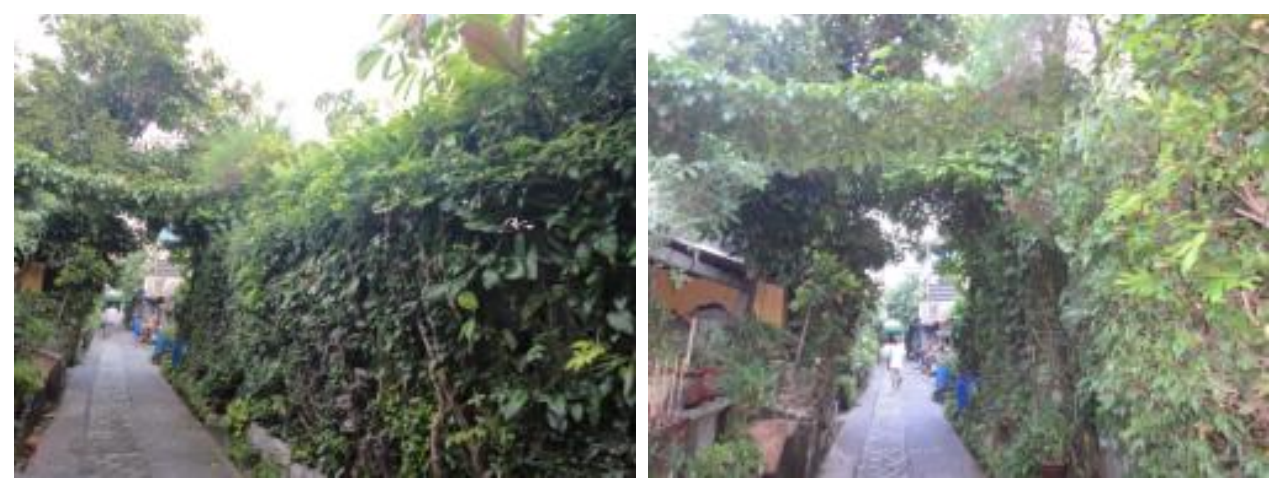

Sumber : Observasi Lapangan, 2013

\section{GAMBAR 2}

KONDISI PENGHIJAUAN DI RW III KELUARAHAN SERENGAN
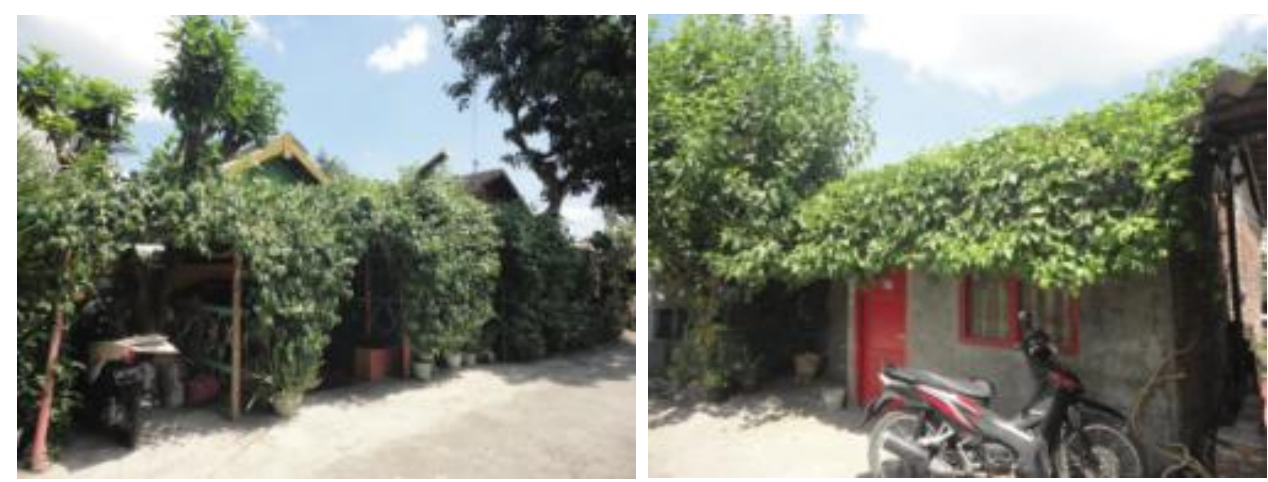

Sumber : Observasi Lapangan, 2013

GAMBAR 3

KONDISI PENGHIJAUAN DI RW XIV DAN RW XV KELURAHAN SERENGAN

\section{KAJIAN BENTUK KETERLIBATAN MASYARAKAT DALAM UPAYA PENGHIJAUAN PADA KAWASAN HUNIAN PADAT DI KELURAHAN SERENGAN - KOTA SURAKARTA}

Partisipasi masyarakat sering diartikan keikutsertaan, keterlibatan dan kesamaan anggota masyarakat dalam suatu kegiatan tertentu baik secara langsung maupun tidak langsung, sejak dari gagasan, perumusan kebijakan, pelaksanaan program dan evaluasi. Partisipasi secara langsung berarti anggota masyarakat tersebut ikut memberikan bantuan tenaga dalam kegiatan yang dilaksanakan. Sedangkan partisipasi tidak langsung dapat berupa sumbangan pemikiran, pendanaan dan material yang diperlukan (Wibisono, 1989;41). Menurut Cohen dan Uphoff (1977), pengertian partisipasi adalah keterlibatan aktif masyarakat dalam proses pengembilan keputusan, pelaksanaan, pemanfaatan hasil dan evaluasi. Pengertian partisipasi lainnya didefinisikan oleh Sajogyo (1998) sebagai peluang untuk ikut menentukan kebijaksanaan pembangunan serta peluang ikut menilai hasil pembangunan.

Masyarakat menurut Kamus Besar Bahasa Indonesia (1988), adalah sejumlah manusia dalam arti seluas-luasnya dan terikat oleh suatu kebudayaan yang mereka anggap sama. Ada banyak ahli sosiologi yang mendefinisikan masyarakat dari berbagai perspektif yang berbeda. Menurut Hasansulama (1983), membedakan masyarakat pengertian sebagai berikut: a). Masyarakat adalah sekelompok manusia yang dengan cara teratur bekerja sama atas dorongan 
hasrat-hasrat sosial yang biasa disebut sebagai sifat-sifat naluriah manusia. b). Masyarakat adalah segolongan manusia dalam keadaan berhubungan yang tetap atau agak tetap, yang diorganisir aktivitas-aktivitas bersamanya, dan yang merasa terikat kepadanya.

Penghijauan adalah salah satu kegiatan penting yang harus dilaksanakan secara konseptual dalam menangani krisis lingkungan. Penghijauan dalam arti luas adalah segala daya untuk memulihkan, memelihara dan meningkatkan kondisi lahan agar dapat berproduksi dan berfungsi secara optimal, baik sebagai pengatur tata air atau pelindung lingkungan (Kelvin,2008). Penghijauan adalah suatu usaha menanami lahan-lahan kritis, baik dari segi hidroorologis, fisik, teknis maupun sosial ekonomi, dengan jenis tanaman tahunan atau perumputan, serta pembuatan bangunan pencegah erosi tanah di areal yang tidak termassuk areal hutan negara (Manan, 1978). Menurut Malau (2012), penghijauan sangat dibutuhkan untuk menciptakan lingkungan yang sejuk, segar, nyaman dan sehat. Namun, dalam pelaksanaan penghijauan masih acapkali ditemukan hal yang tidak tepat sasaran sehingga aksi penghijauan yang dilakukan kurang (tidak) menghasilkan manfaat yang besar atau maksimal. Banyak faktor menyebabkan pelaksanaan penghijauan itu tidak tepat sasaran. Dari banyak faktor itu dapat dikelompokkan menjadi dua kelompok besar yakni faktor non teknis dan faktor teknis.

Menurut Kuswartojo dan Salim, (1997:21) Permukiman adalah perumahan dengan segala isi dan kegiatan yang ada di dalamnya. Permukiman dapat dirumuskan sebagai suatu kawasan perumahan yang ditata secara fungsional sebagai satuan sosial, ekonomi, dan fisik tata ruang, dilengkapi dengan prasarana lingkungan, sarana umum dan fasilitas sosial (Doxiadis, 1971). Jain (1987) menyatakan bahwa setiap wilayah pemukiman memiliki tingkat kepadatan yang berbeda dengan jumlah unit rumah tinggal pada setiap struktur hunian dan struktur hunian pada setiap wilayah pemukiman. Kepadatan tinggi merupakan stressor lingkungan yang dapat menimbulkan kesesakan bagi individu yang berada didalamnya (Holahan,1982). Stressor lingkungan menurut Brigham, (1991) merupakan salah satu aspek lingkungan yang dapat menyebabkan stress, penyakit atau akibat-akibat negatif pada perilaku masyarakat. Menurut Heimstra dan Mc Farling (1978) kepadatan memberikan akibat bagi manusia baik secara fisik, sosial maupun psikis.

\section{ANALISIS BENTUK KETERLIBATAN MASYARAKAT DALAM UPAYA PENGHIJAUAN PADA KAWASAN HUNIAN PADAT DI KELURAHAN SERENGAN - KOTA SURAKARTA}

\section{Analisis Persepsi Masyarakat Terhadap Lingkungan Huniannya}

Dari hasil analisis ditemukan bahwa alasan tinggal warga di Kelurahan Serengan, yaitu karena alasan untuk menempati rumah warisan, alasan karena lingkungan masih asri, alasan karena dekat dengan tempat kerja, serta alasan harga lahan yang masih murah. Jika dikaitkan dengan aktivitas bermukim, maka pendapat Carter (1981) mengenai pertimbangan yang mempengaruhi preferensi bermukim perlu diperhatikan mengingat perkembangan suatu kawasan sangat dipengaruhi oleh preferensi orang untuk mengakses kawasan tersebut. Hal ini telah terjadi di Kelurahan Serengan seiring dengan munculnya keinginan masyarakat untuk tinggal karena alasan dekat dengan tempat kerja mereka. Alasan seseorang untuk tinggal di suatu kawasan, antara lain adalah harga lahan atau rumah yang terjangkau kemampuan ekonomi, akses lokasi, kelengkapan sarana dan prasarana, biaya transportasi, jarak lokasi bermukim ke lokasi kerja dan pusat aktivitas, kondisi fisik lingkungan sekitar, estetika dari arsitektur dan kawasan, serta kondisi sosial dan lingkungan (Carter, 1981). Keterbatasan ruang perkotaan yang sifatnya statis menyebabkan terjadinya alternatif-alternatif dalam mencari 
kebutuhan ruang untuk tempat tinggal dan akan merambah pada lahan-lahan kosong di luar pusat kota sehingga membentuk suatu konsentrasi baru (Yunus, 2008). Ketersediaan lahan yang terbatas telah menyebabkan semakin terdesaknya area-area kosong yang ada di Kelurahan Serengan berubah menjadi kawasan terbangun.

Kenyamanan Hunian. Sebanyak 41\% responden berpendapat bahwa Kelurahan Serengan sudah tidak nyaman/panas. Dari beberapa nasasumber juga disebutkan bahwa lingkungan hunian mereka sekarang ini sudah terasa panas. Mereka beralasan bahwa kelurahan ini dulunya cukup rindang, akan tetapi karena banyaknya pendatang banyak pohon-pohon yang ditebang untuk ruang hunian. Ketidaknyamanan juga dapat dilihat dari tingkat keleluasaan aksesibilitas yang ada di kelurahan ini. Hal ini adalah salah satu alasan mereka mengatakan bahwa lingkungan hunian mereka tidak nyaman. Sebanyak $37 \%$ menyatakan masih nyaman. Warga merasa nyaman karena memang hanya dilingkungan tersebut mereka mempunyai properti. Faktor ekonomi merupakan penyebab masyarakat mau menerima keadaan mereka, sehingga mereka tetap merasa nyaman untuk tinggal di kelurahan ini. Sebanyak 22\% menyatakan biasa saja. Sebagian masyarakat menilai tingkat kenyamanan di kelurahan ini biasa saja, hal ini karena dari awal mereka datang keadaannya sudah demikian sehingga mereka merasa tidak ada perubahan yang terjadi. Hal ini berbeda dengan yang dialami oleh sebagian warga yang sudah bertahun-tahun tinggal, pasti mereka bisa melihat perbedaan antara lingkungan mereka yang dulu dengan yang sekarang ini. Berkembangkan Kelurahan Serengan menjadi kawasan hunian padat di kawasan pinggiran tidak terlepas dari adanya pengaruh urbanisasi di Kota Surakarta. Dengan mahalnya harga lahan dipusat kota mendorong kepentingan masyarakat untuk bermigrasi kepinggiran kota. Pertumbuhan penduduk akibat urbanisasi telah memacu perkembangan wilayah kota yang menyebar dan memicu konsentrasi-konsentrasi aktivitas perkotaan yang baru yang didukung dengan meningkatnya wilayah yang memiliki ciri kekotaan (Angotti, 1993).

Kepadatan Hunian. Kepadatan mencakup banyak dimensi. Kepadatan tidak hanya mencakup dimensi fisik seperti ukuran jumlah penduduk per wilayah atau jumlah orang per rumah (kepadatan hunian dan kepadatan rumah) akan tetapi juga mengandung aspek sosial, ekonomi, dan lain-lain. Berdasarkan penilaian dari 100 responden, ketika ditanya mengenai tingkat kepadatan di Kuraharan Serengan, sebanyak: $81 \%$ responden berpendapat bahwa tingkat kepadatan cukup tinggi, 14\% merasa tingkat kepadatan pada kelurahan ini masih sedang, dan $5 \%$ berpendapat bahwa tingkat kepadatan masih rendah.

\section{Analisis Persepsi Masyarakat Terhadap Kondisi Ruang Hijau}

Dari hasil analisis yang telah dilakukan diketahui bahwa masyarakat di Kelurahan Serengan menilai penghijauan dilingkungan mereka masih kurang. Sebanyak $86 \%$ menyatakan masih kurang. Hampir 100\% responden yang ada di RW1, RW8, RW9, RW12, dan RW14 menyatakan bahwa penghijauan kota di lingkungan RW mereka masih kurang. Ketika ditanya apakah mereka memiliki penghijauan dipekarangan mereka, hampir $99 \%$ responden menyatakan bahwa mereka memiliki meskipun dengan berbagai bentuk dan ukuran yang berlainan. Tingkat pendidikan dan tingkat pendapatan masyarakat bisa dikatakan saling berpengaruh terhadap bentuk-bentuk penghijauan yang dilakukan oleh masyarakat. Umumnya masyarakat dengan penghasilan menengah keatas (diatas 2 juta) telah memiliki konsep penghijauan pekarangan/taman sendiri di halaman mereka masing-masing dengan jenis tanaman hias, bunga-bungaan, anturium, tanaman buah, bonsai, dan berbagai tanaman lain yang memiliki nilai cukup mahal. Kondisi ini berbeda dengan masyarakat yang memiliki ekonomi rendah, mereka biasanya tidak memiliki taman, jika pun ada penghijauan di pekarangan mereka itu pun adalah jenis tanaman liar dan umumnya berupa tanaman keras. Menanamnya pun tidak 
berdasarkan konsep dan mengindahkan nilai-nilai estetika/asal tanam. Sebanyak 14\% menyatakan sudah cukup. Hal ini senada dengan pendapat Yuliantoro \& Damayanti, (2008) yang menyatakan bahwa kapasitas ekonomi diperlukan sebagai faktor yang menentukan dan mendukung kesejahteraan. Masyarakat yang menyatakan bahwa penghijauan dilingkungan mereka cukup biasanya pada lingkungan tersebut sudah terdapat taman atau pun jenis penghijauan lainnya. Contohnya di RW X, XI, dan XIII sebagaian masyarakat menyatakan bahwa penghijauan di kawasan mereka cukup, karena pada RW-RW ini telah terdapat taman tanggul dengan panjang kurang lebih 800 meter.

\section{Analisis Preferensi Masyarakat Melakukan Penghijauan}

Menurut Hakim, dkk (2008), ada beberapa manfaat dari adanya penghijauan, antara lain: memberi kesegaran, kenyamanan dan keindahan lingkungan, memberikan lingkungan yang bersih dan sehat bagi penduduk kota, daun, bunga dan buah, sebagai tempat hidup satwa dan plasma nutfah, sebagai resapan air guna menjaga keseimbangan tata air dalam tanah, mengurangi aliran air permukaan, menangkap dan menyimpan air, menjaga keseimbangan tanah agar kesuburan tanah tetap terjamin, sirkulasi udara dalam kota, dan sebagai tempat sarana dan prasarana kegiatan rekreasi. Hakim, dkk (2008), juga memberikan gambaran bahwa penghijauan sangat bermanfat bagi pengembangan kota, antara lain sebagai penunjang keindahan (estetika) dan mempertinggi kualitas ruang kehidupan lingkungan. Hal ini juga terjadi di Kelurahan Serengan. Jika dikaitkan dengan pendapat diatas, maka ada beberapa kesamaan terkait motif dari masyarakat di Kelurahan Serengan melakukan penghijauan, antara lain: masyarakat melakukan hijuan kota untuk menambah nilai ekologi maupun estetika pada ruang hunian mereka, alasan untuk mendapatkan nilai ekonomi, serta alasan lainnya adalah untuk menjalankan kewajiban karena merupakan program pemerintah.

1. Penghijauan untuk menambah ekologi kawasan. Menurut pandangan masyarakat, penghijauan dapat dijadikan sebagai suatu sarana untuk menurunkan suhu udara dilingkungan mereka yang cukup panas akibat kepadatan bangunan yang cukup tinggi. Penghijauan kota dapat digunakan sebagai paru-paru kota yang dapat memberikan perlindungan terhadap angin, debu, sinar matahari, bunyi dan lain-lain. Penghijauan kota dapat digunakan untuk meresap air hujan, guna menjamin persediaan air tanah di lingkungan mereka tinggal. Untuk kawasan bantaran sungai masyarakat mengembangkan penghijauan kota sebagai sarana mitigasi bencana seperti untuk mencegah terjadinya erosi, terutama pada kawasan bantaran sungai jenes yang meliputi RW IX, X, XII, XIV, dan $\mathrm{XV}$.

2. Penghijauan untuk menambah estetika kawasan. Menurut Pandangan Masyarakat, penghijauan dapat menambahkan kualitas estetika dan dimensi manusia dengan desain lingkungan untuk penciptaan ruang yang lebih menyenangkan. Penghijauan dapat meningkatkan permeabilitas ruang untuk menjaga keseimbangan yang kosong dan massa untuk kontras visual dalam lingkungan bangunan rumah yang ada. Masyarakat juga berpendapat bahwa lingkungan yang hijau dan asri akan menambah nilai estetika suatu lingkungan yang akan berdampak pada kesehatan jiwa.

3. Penghijauan untuk menambah nilai ekonomi. Menurut Pandangan Masyarakat, penghijauan sebagai sumber produk yang bisa dijual atau untuk memenuhi kebutuhan hidup manusia, seperti tanaman bunga, buah, daun, sayur mayur. Untuk warga yang memiliki pekarangan sempit mereka lebih suka untuk memilih jenis tanaman hias maupun tanaman obat (toga). Penghijauan dengan tanaman keras dapat diambil kayu maupun buahnya. seperti mangga, jambu, matoa dan tanaman lainnya adalah tanaman penghijauan pilihan warga di Kelurahan Serengan.

4. Penghijauan untuk mendukung program pemerintah. Menurut Pandangan Masyarakat, Kegiatan penghijauan adalah tangungjawab bersama antara pemerintah, masyarakat, 
swasta, maupun pihak terkait lainnya. Pemerintah sebagai pemangku kebijakan berkewajiban untuk menyelenggarakan program-program bagi masyarakat. Masyarakat sendiri bisa berperan sebagai subyek maupun obyek dari kebijakan pemerintah khususnya terkait penghijauan di skala basis.

\section{Analisis Peran Stakeholder Dalam Upaya-Upaya Penghijauan}

Keberadaaan stakeholder yang terdiri dari Pemerintah Kota, Pemerintah Kelurahan, Lembaga Non Pemerintah, Swasta/CSR, dan Komunitas/Akademisi telah berkontribusi besar membantu perkembangan kegiatan penghijauan di wilayah studi. Berdasarkan hasil penelitian yang telah dilakukan, diketahui peran peran masing-masing stakeholder tersebut.

1. Peran Pemerintah Kota. Dalam kegiatan penghijauan yang telah dilaksanakan di Kelurahan Serengan, Pemerintah Kota banyak membantu dari segi perencanaan maupun pelaksanaan. Dari segi perencanaan, Pemerintah Kota telah melibatkan masyarakat mengenai konsep-konsep penghijauan melalui berbagai kegiatan pemberdayaan masyarakat dalam upaya-upaya penghijauan. Dari sisi pelaksanaan Pemerintah Kota banyak berperan dalam pembiayaan untuk pembangunan fisik, seperti pada pembuatan tamantaman kota, pengadaan bibit untuk turus/jalur hijau jalan dan penghijauan publik lainnya.

2. Peran Pemerintah Kelurahan. Pemerintah Kelurahan Serengan telah berperan dalam Pengembangan kapasitas warga terkait penghijauan lingkungan melalui peningkatan ketrampilan usaha di bidang terkait, seperti: Pelatihan tentang budidaya tanaman hias dan pupuk organik kepada kelompok tani tanaman hias "Serengan Asri" yang berlokasi di RT 03 RW III Kelurahan Serengan, Pelatihan tentang budidaya tanaman jarak, tanaman buah, dan sayuran kepada Kelompok tani Tanaman Keras "Sambung Urip" di RT 04 RW XII Kelurahan Serengan. Pelatihan produksi sampah organik kepada kelompok Pengelola Sampah Organik "Serengan Go Green" di RT 01 RW 10 Kelurahan Serengan. Pemerintah Kelurahan juga telah mengajak masyarakat untuk melakukan penanaman pohon dilingkungan masing-masing sehingga menambah ruang hijau privat dan melaksanakan pagar hijau dengan menanami tanaman hijau dan jika tetap mempertahankan pagar hijau harus dilengkapi tanaman merambat.

3. Peran Lembaga Non Pemerintah. Salah satu Lembaga Non Pemerintah yang ada di kelurahan Serengan adalah Lembaga Pemberdayaan Masyarakat Kelurahan (LPMK). Beberapa hal yang dapat dilakukan LPMK Kelurahan Serengan dalam upaya penghijauan di Kelurahan Serengan antara lain: Mendorong dan/atau menfasilitasi proses pembelajaran masyarakat untuk memecahkan masalah yang berhubungan dengan penyediaan ruang hijau. Kegiatan ini dapat berupa pemberian pelatihan kepada masyarakat dan/atau yang terkait hijauan kota, maupun dengan proses diskusi dan seminar.

4. Peran Swasta/CSR. Swasta/CSR berperan dalam program penghijauan di Kelurahan Serengan dengan cara membagi-bagikan bibit penghijauan secara gratis. Bagi masyarakat yang memiliki tanah kritis dan tidak dapat dimanfaatkan dapat meminta bibit kepada perusahaan agar dapat ditanami. Bentuk CSR lain yang diberikan ke Kelurahan Serengan adalah program tanaman dalam pot lokasi depan pertokoan sepanjang jalan Yos Sudarso dari tanggul sampai perempatan Gemblengan dan depan pertokoan sepanjang jalan Veteran dari perempatan sampai patung pahlawan wilayah Kelurahan Serengan.

5. Peran Komunitas/Akademisi. Adapun komunitas yang aktif dalam kegiatan penghijauan di Kelurahan Serengan antara lain adalah Komunitas Solo Berkebun, Komunitas Green Movement Club (GMC) UNS, dan Komunitas IAAS LC UNS. Dalam upaya penghijauan di Kelurahan Serengan, Komunitas Solo Berkebun, sangat mambantu warga terutama ibu-ibu dan anak usia sekolah mengenal penghijauan lingkungan dengan cara bercocok tanam dilingkungan masing-masing. Adapun yang telah dilkuakan komunitas ini antara lain adalah program kampung hijau dan kegiatan berkebun di sekolah/kampus. Komunitas GMC telah 
melakukan pendampingan masyarakat dalam membangun kampung hijau, penanaman dan perawatan tanaman langka, serta ikut serta dalam pengembangan ruang hijau kota dengan sistem roof garden. Komunitas IAAS telah membantu masyarakat Kelurahan Serengan dalam pembuatan taman obat keluarga (Toga). Contohnya di RW II, yang kebetulan memiliki lahan yang cukup luas untuk tempat pembelajaran. Dengan pendampingan yang dilakukan secara berkala kini kami sudah bisa mengembangkan di masing-masing rumah.

\section{Analisis Bentuk Ketelibatan Masyarakat Dalam Upaya Penghijauan}

Beberapa bentuk keterlibatan masyarakat yang cukup penting dalam penghijauan di Kelurahan Serengan, antara lain masyarakat perlu terlibat dalam kegiatan perencanaan, pelaksanaan, pemeliharaan, dan pengawasan

1. Keterlibatan Masyarakat dalam Perencanaan. Peran serta masyarakat dalam perencanaan yaitu meliputi pemberian masukan berupa informasi, usul-usul, saran, melalui pertemuan untuk bahan perencanaan penghijauan. Terdapat $19 \%$ responden yang menyatakan bahwa mereka pernah memberikan masukan untuk perencanaan penghijauan. Adapun masukan yang diusulkan masyarakat antara lain: jenis tanaman untuk penghijauan, waktu penyediaan bibit atau penyerahan tanaman untuk penghijauan, dan usul lainnya yang berkaitan dengan teknis penghijauan.

2. Keterlibatan Masyarakat dalam Pelaksanaan/Penyediaan. Terdapat $43 \%$ responden yang menyatakan bahwa mereka terlibat dalam penghijauan di kelurahan Serengan dalam bentuk penyediaan. Masyarakat Kelurahan Serengan rata-rata memiliki pendidikan cukup tinggi. Sebanyak 34\% responden yang diwawacara memiliki latar belakang pendidikan sebagai lulusan perguruan tinggi. Terkait dengan penyediaan ruang hijau kota di Kelurahan Serengan, warga secara mandiri telah merancang sendiri bagaimana bentuk-bentuk penghijauan kota yang sesuai dengan lingkungan mereka tinggal. Keberadaan kelembagaan lokal yang ada di Kelurahan Serengan juga sangat berberan didalam menumbuhkan kesadaran masyarakat terhadap lingkungan, salah satunya dalam hal pengembangan ruang hijau kota (Pembibitan tanaman, pemilihan jenis tanaman, cara menanam, dan sebagainya). Pada sisi penghasilan, diketahui bahwa sekitar $40 \%$ responden memiliki penghasilan diatas Rp 2 juta. Jika dikaitkan dengan penyediaan ruang hijau kota maka dapat diketahui keterkaitannya. Umumnya warga dengan penghasilan diatas Rp 2 juta telah memiliki penghijauan pekarangan sendiri.

3. Keterlibatan Masyarakat dalam Pemeliharaan. Umumnya masyarakat Kelurahan Serengan melakukan pemeliharaan pada penghijauan di pekarangan masing-masing. Sekitar $23 \%$ responden menyatakan mereka turut terlibat dalam pemeliharaan hasil-hasil penghijauan yang telah dilaksanakan di kelurahan ini. Untuk Pemeriharaan pada penghijauan publik seperti: taman lingkungan yang ada disudut-sudut RW, jalur hijau jalan di depan rumah warga, dan tanggul sungai pemeliharaan sifatnya sukarela dan merupakan kesadaran warga sendiri.

4. Keterlibatan Masyarakat dalam Pengawasan. Sebanyak $15 \%$ responden menyatakan mereka terlibat dalam penghijauan dalam bentuk pengawasan. Bentuk pengawasan yang telah dilakukan warga saat ini salah satunya adalah mempertahankan keberadan hijauan kota yang terdapat di kawasan tanggul sungai. Dalam penghijauan, pengawasan adalah rangkaian kegiatan yang harus dilaksanakan masyarakat dan pemerintah dengan sungguhsungguh. Tanpa pengawasan yang baik tujuan penghijauan sulit dicapai. Peran serta masyarakat dalam pengawasan dapat dinilai dari pelaporan masyarakat kepada aparat birokrasi yang berwenang dalam mengelola penghijauan mengenai hal-hal yang seharusnya tidak terjadi di lapangan. 


\section{KESIMPULAN}

Penduduk di kawasan Kampus UNDIP Tembalang memiliki preferensi tinggal yang memandang tempat tinggal dengan fungsi bermukim dan ekonomi yang strategis. Penduduk yang pada akhirnya menetap di sana baik itu secara alamiah karena turun temurun, terpaksa karena direlokasi UNDIP, atau yang memang memilih karena tertarik adanya peluang usaha dan kenyamanan lokasi dan kondisi alam, semuanya menyadari bahwa ada daya tarik tersendiri di sana. Mereka tidak hanya memilih menetap karena ada tempat tinggal sebagai tempat beristirahat, tapi juga melihat adanya sumber pemasukan keuangan. Kawasan yang padat dan berkembang serta didukung dengan kestabilan kondisi alam yang baik, membuat penduduk setempat memilih tinggal di sana baik itu pendatang maupun warga asli yang bertahan.

Setelah memutuskan untuk menetap, penduduk asli harus menyadari bahwa situasi dan kondisi di lingkungan mereka berubah. Kondisinya yang mengancam keberlangsungan menetap penduduk asli adalah pendatang memiliki kemampuan ekonomi lebih baik sehingga jika warga asli ekonominya terdesak akhirnya akan pindah. Maka penduduk asli harus bisa melakukan adaptasi yang dilakukan sebagai upaya untuk meningkatkan taraf hidup. Dengan tujuan ingin meningkatkan kondisi ekonomi mereka yang sebelumnya hanya tergantung pada pertanian dan menjadi buruh, maka jika ingin bertahan mereka dituntut untuk mampu memanfaatkan peluang usaha sebagai tambahan penghasilan. Kondisi ekonomi yang membaik akan memperkuat posisi mereka untuk tetap tinggal dan memampukan mereka untuk meningkatkan kondisi rumah mereka karena mereka juga menyadari lingkungan fisik mereka berkembang lebih bagus setelah banyak dimasuki pendatang. Bagi mereka yang bertahan juga berusaha menyesuaikan gaya hidup perkotaan yang mereka anggap masih sesuai dengan norma setempat karena mereka masih mempertahankan tradisi lama di lingkungan. Pada akhirnya mereka berupaya untuk meningkatkan taraf hidup mereka agar lebih baik lagi dan menyesuaikan diri dengan lingkungan mereka yang kondisinya juga meningkat.

Seiring dengan adaptasi yang dilakukan penduduk asli yang bertahan, mereka sendiri bisa mengobservasi dari perubahan yang mereka lihat di lingkungan sehingga mereka menyadari ada lesson learned yang dapat mereka ambil. Persepsi mereka terhadap pendatang, penduduk asli yang pindah, serta terhadap lingkungan bisa mereka jabarkan dari sisi positif dan negatifnya. Mereka tetap terbuka pada pendatang karena mereka menyadari pendatang juga yang memberi perubahan di lingkungan sehingga lebih maju, namun penduduk asli juga tetap mengajak pendatang untuk berbaur dalam tradisi dan keguyuban lingkungan yang dipertahankan di tengah modernitas perkotaan. Seiring masuknya pendatang, mereka melihat tetangga mereka yang warga asli pindah karena terdesak secara ekonomi. Dari situ mereka belajar untuk tidak mengulangi kesalahan warga asli yang tidak bisa meningkatkan kondisi ekonomi karena malas, kurang bisa memanfaatkan peluang usaha, tidak bisa mengelola keuangan. Mereka menyadari kemajuan lingkungan mereka yang mengalami urbanisasi dengan berbagai fasilitas yang lebih lengkap dan infrastruktur yang lebih baik. Di sisi lain, mereka juga harus menerima konsekuensi kawasan yang semakin padat. Pada dasarnya mereka yang bertahan menyadari bagaimana harus menyikapi dampak positif dan negatif dari lingkungan mereka yang berubah.

\section{DAFTAR PUSTAKA}

Angotti, T. 1993. Metropolis 2000, Planning, Poverty and Politics. New York: Routledge. Arikunto, Suharsimi. 2000. Manajemen Penelitian. Jakarta: Rineka Cipta. 
Arum, Tika Sekar. 2009. Bukti Pemberdayaan Serengan tak Pernah Mati. Suara Merdeka, 25 Juni 2009. Hal-8.

Brigham, J.C. 1991. Social Psychology. New York: Harpercollins Publisher.

Carter, Harold. 1981. The Study of Urban Geography. London: Edward Arnold.

Cohen. Uphoff. 1977. Rural Development Participation: Concept and Measures For Project Design Implementation and Evaluation. New York: Rural Development Commite- Cornel University.

Depdikbud. 1988. Kamus Besar Bahasa Indonesia. Jakarta: Balai Pustaka.

Doxiadis C.A. 1971. Ekistics: An Introduction to the Science of Human Settlement. London: Hutchinson.

Hasansulama, M.I. dkk. 1983. Sosiologi Pedesaan. Jakarta: Departemen Pendidikan dan Kebudayaan.

Heimstra, N.W dan Mc Farling, L.H. 1978. Enviromental Psychology 2nd Edition Brooks / Cole Publishing Company California.

Holahan, C. J. 1982. EnvironmentalPsychology. New York: Random House.

Jain. U. 1987. The Psychological Consequences of Crowding. New Delhi: Sage Pub. India Ltd.

Kelvin, Claudius. 2008. Penghijauan Kota Sebagai Penyeimbang Suhu Lingkungan. Jakarta: claudiuskelvin.blogspot.com/2008/09/pengertian-penghijauan.

Kuswartojo T. dan Salim S.A. 1997. Perumahan dan Permukiman yang Berwawasan Lingkungan. Jakarta: Direktorat Jenderal Pendidikan Tinggi, Departemen Pendidikan dan Kebudayaan.

Malau, Fadmin Prihatin. 2012. Penghijauan Bukan Sekadar Menanam Jutaan Pohon. Tersedia di http://ines.staf.narotama.ac.id/2012/03/06/penghijauan-bukan-sekadar-menanam-jutaanpohon/. Diakses pada tanggal 06 Maret 2012.

Manan, S. 1978. Pengaruh Hutan dan manejemen Daerah Aliran Sungai. Institut Pertanian Bogor. Bogor.

Monografi Kelurahan Serengan, 2012

Prasetyo, Wahyu Tirto. 2013. "Kajian Kualitas Permukiman Dengan Citra Quickbird Dan SIG Di Kecamatan Serengan Kota Surakarta.” Jurusan Perencanaan Wilayah dan Kota, Fakultas Teknik, Universitas Diponegoro.

Sajogyo. 1998. Dimensi Kemiskinan: Agenda Pemikiran Sajogyo. Kumpulan Pemikiran Sajogyo dengan editor: Mukhtar Sarman. Pusat P3R-YAE.

Samsudi. 2010. Ruang Terbuka Hijau Kebutuhan Tata Ruang Perkotaan Kota Surakarta. Fakultas Teknik Universitas Sebelas Maret. Surakarta.

Setianingrum, Rani. 2010. Kelompok Tani Tanaman Hias Serengan Asri - Pernah Alami Masa Kejayaan. Joglosemar, 11 Desember 2010. Hal - 8.

Sihono. 2003. "Peran Serta Masyarakat Dalam Pengelolaan Prasarana Pasca Peremajaan Lingkungan Permukiman di Mojosongo Surakarta." Tesis tidak diterbitkan, Magister Pembangunan Wilayah dan Kota, Program Pascasarjana Universitas Deponegoro, Semarang.

Tyaswening, Restu. 2012. Laporan Kegiatan “Lomba Kelurahan Peduli Hutan” Kelurahan Serengan. Surakarta, 08 Mei 2012.

Vidya, Agni. 2011. Hutan Kota Di Gang Yudhistira, Kreasi Kelompok Tani Serengan. Permak Gang Hijau Jadi Kampung Terbaik. Joglosemar, 20 Februari 2011. Hal - 9

Wibisono, C. 1989. Anatomi dan Profil Konglomerat Bisnis Indonesia. Management dan Usahawan Indonesia, Desember.

Yuliantoro \& Damayanti, M. (2008). Is economic viability the answer for community's QoL Assessment? Tataloka, 10 (1), 37-48.

Yunus, Hadi Sabari. 2008. Dinamika Wilayah Peri-Urban Determinan Masa Depan Kota. Yogyakarta: Pustaka Pelajar. 